\title{
Breaking the Silence on LGBTQ Issues in Saskatchewan: An Interview with Don Cochrane
}

\author{
AndRé P. Grace
}

André P. Grace (andre.grace@ualberta.ca) is an inclusive educator whose current SSHRC-funded research focuses on welfare and work issues for queer teachers in Canada. At the Breaking the Silence Conference in Saskatoon in 2001, he met conference founder Don Cochrane (don.cochrane@usask.ca).Professor Cochrane is Department Head of Educational Foundations in the College of Education, University of Saskatchewan. In 2000 he received the Doug Wilson Award for his significant contributions to improving the quality of life for lesbian, gay, bisexual, and transgender persons on the University of Saskatchewan campus.

In the case of gays, history and experience teach us that the scarring comes not from poverty or powerlessness, but from invisibility. It is the tainting of desire, it is the attribution of perversity and shame to spontaneous bodily affection, it is the prohibition of the expression of love, it is the denial of full moral citizenship in society because you are what you are, that impinges on the dignity and self-worth of a group.

- Judge Albie Sachs, Constitutional Court of South Africa, 1998, as quoted in Crimes of Hate, Conspiracy of Silence, Amnesty International (vii)

I attended my first Breaking the Silence Conference at the University of Saskatchewan in March 2001. I expected a conference where university interest groups deliberated with community interest groups about LGBTQ (lesbian, gay, bisexual, transgender, and queer) issues and concerns. I encountered that energizing scenario, plus another disconcerting one that reminded me how LGBTQ educational and cultural work takes place at the dangerous intersection of the moral and the political. I reflect on my conference experience in the following narrative vignette: 


\section{Breaking the Silence: \\ Making Queer Visible, \\ Confronting the Denial of Full Moral Citizenship}

On the weekend of March 17,2001, more than one hundred LGBTQ persons and straight allies came together for the 4th annual Breaking the Silence Conference at the University of Saskatchewan in Saskatoon. We assembled in the Quance Lecture Theatre in the College of Education to share, dialogue, and deliberate as a spectral community of educators, community activists, and cultural workers who work at the intersections of sex-and-gender differences, education, and culture. Each time we entered the education building, we had to run the gauntlet of a small group of homophobic 'Christians' who provided us with one more experience of hell on heteronormative earth. They carried placards that slandered us with phrases such as "Sodomy will destroy our school systems"; "Jesus Christ can heal the homosexual"; and "Don't let sodomy ruin our children." Maligning phrases like these demonize LGBTQ persons in a scourging, exclusionary, defiling 'Christian' language that suggests that we are sick, deviant, and disgusting perpetrators of abomination. Inspired by Old Testament narratives like Romans I, such scurrilous, heteronormalized 'Christian' language is the abomination.

In effect, the socially repulsive goal of these 'Christians' is to deny us the prospect of full moral citizenship. Despite the anger and rage that the encounter with them stirred in me, it was worth running their gauntlet. Not only did it remind me why I had come to Saskatoon, it also made me appreciate the passion and exuberance of the inclusive community that I found inside the education building.

Maybe someday conferences like Breaking the Silence won't have to exist as an oasis in the midst of the social and cultural exclusion that LGBTQ citizens experience every day. Maybe someday all $L G B T Q$ persons will be safe - physically, psychologically, emotionally - from homophobic 'Christians' who fuel an $L G B T Q /$ straight binary and demean $L G B T Q$ differences with their dismissal, denial, and denigration of those they other as deviant and disturbed. Maybe someday we will be considered full citizens, whole persons, real Canadians. I am hopeful. I witnessed the power of LGBTQ people and straight allies at Breaking the Silence in Saskatoon. I witnessed people in community engaged in a human and civil rights movement. I saw people smiling, hugging, speaking 
out, and creating dialogic and deliberative spaces. I heard them talking about inclusive education and community work that transgresses heteronormative exclusion. I heard them commit to taking incremental actions to raise LGBTQ visibility in homes, schools, colleges, shopping malls, and other sociocultural sites where heterosexism is visible in word, action, and representation. I reveled to be there in this sharing and nurturing space, a space where I was one proud queer and inclusive educator.

The 2001 Breaking the Silence Conference proved such an exhilarating experience for me that $I$ decided to make attending this annual event a spring ritual. Meeting Don Cochrane at this conference was a highlight for me. I remain inspired and heartened by the commitment of this educator-activist who continues his work to enhance LGBTQ human and civil rights in Canadian education and culture. As a straight ally, Don has been a risk taker in his transgressive educational and cultural work that helps LGBTQ persons to have presence and place in his university and province. I have truly enjoyed getting to know Don, and I was pleased when he made the trek to Edmonton in Fall 2002 to attend Sex-and-Gender Differences, Education, and Culture II, an annual conference complementary to Breaking the Silence that we host in the Faculty of Education, University of Alberta. Don lives out a public pedagogy of respect and care in his life, work, and teaching-learning interactions. In the interview that follows, I ask Don to trace the genesis of Breaking the Silence. Over the course of the interview he discusses his own emergence as an LGBTQ-inclusive educator, and he provides insights and pointers for those who wish to engage in work that recognizes, respects, and fosters LGBTQ differences in university and community settings.

André: Don, at the 2002 conference we celebrated the fifth anniversary of the Breaking the Silence: Gays and Lesbians in Our Schools Conference. This was an important milestone. As everyone sang "Happy Birthday" and shared cake, there was a sense that the annual conference was making a difference. What was it like in the College of Education, University of Saskatchewan, before the conference and other initiatives to profile LGBTQ issues and concerns? 
Don: Let me begin by noting that an amendment to the Saskatchewan Human Rights Code in 1993 guaranteed our province's teachers equality of employment opportunity irrespective of their sexual orientation. ${ }^{1}$ Of the province's more than twelve thousand teachers, we can speculate that at least a thousand are lesbian or gay. Yet, only a small handful is openly out. At best, the majority of these teachers experience a high degree of social alienation; at worst, they fear losing their economic livelihood, the human rights code notwithstanding.

Despite the amendment, straight colleagues continued to sit on the sidelines. They did not get involved in LGBTQ issues. "Why?" I wondered. There were many reasons. Some thought that homosexuality is a religious matter or a 'choice of life-style.' Others regarded it as a mental illness, even though the American Psychiatric Association had expunged homosexuality from its Diagnostic and Statistical Manual of Mental Disorders (DSM) in $1973 .^{2}$ Some saw it as 'their battle, not mine.' Others claimed that they did not know any lesbian or gay teachers, and so, did not know whom to help. Still others ducked responsibility, claiming the college should wait until society as a whole resolves the issues.

These are roughly political reasons — one might say, "rationalizations." I guessed that fear played a major role in professional inaction. Many liberal straight educators were afraid of being 'tainted' if they supported their lesbian and gay colleagues. Some older members of the profession remembered the price paid by 'nigger lovers' during the civil rights movement in the 1960s; supporting 'fags' would fall into the same category in the 1990s. Still I wondered, "What would straight educators need to support a cause that would be sanctioned by their province's human rights code and backed by the Canadian Charter of Rights and Freedoms?"

André: Obviously, the inaction of many colleagues affected you. Could you speak further to what spurred you to become more personally involved in addressing LGBTQ issues and concerns?

' See Section 16.1 of The Saskatchewan Human Rights Code (Saskatchewan).

2 The American Psychiatric Association and the American Psychological Association both declassified homosexuality as a mental disorder in 1973 (see Katz; and Norman Institute). 
Don: As a philosopher of education, I have always been interested in the intersection of ethics and education, and so our failure to address the obvious repression of lesbians and gays in our university and in our schools had puzzled me. Although I could pose important ethical and practical questions, I knew that I was part of the problem. It was hypocritical of me to view teachers with disdain if I did nothing to raise these challenging issues with my own colleagues and students. Indeed, I was probably more culpable: I was a university professor protected by tenure, yet I was as silent as the rest. I was not proud of my own inaction. But what would I say, and where, and with what authority? My trepidation was only outstripped by my ignorance! Nothing in my own education had prepared me to break my own silence.

André: But you did break your own silence! How did you overcome these hurdles and get started?

Don: My first step was to create a course on lesbian and gay issues in education, and so began one of the most important and rewarding journeys of my life. I began by meeting with a small group of lesbian and gay students from a campus club, almost to seek their permission. I figured that if they would not approve the idea, the idea would be dead in the water. To my surprise, they were very supportive. They promised any help they could offer. Why was I surprised? Perhaps I had been too influenced by 'appropriation-of-voice' critics. I had heard of bad scenes at some other Canadian universities. These students seemed to appreciate that someone - indeed anyone would raise these issues at their university:

Buoyed by this support, I started a crash self-education program in lesbian and gay issues. Eventually I organized my material under these general headings:

1. Introducing lesbian and gay courses in the university

2. Lesbian and gay teachers

3. Lesbian and gay students

4. The inclusive curriculum (with special emphasis on health education, literature and language, and physical education)

5. The inclusive library

6. The challenge to counselors 
Looking at the course today, I wonder what all the fuss was about when our department sought approval from faculty. It was as if approving the course would result in the walls of our college imploding. A few colleagues opposed the course altogether, and several others, harboring fears, pleaded for more time. After some lively discussion, the course was approved handily. When the meeting ended, supporters gathered for hugs; we knew we had done something good that day. In my thirty years in the academy, I had never experienced hugs after a faculty meeting!

I taught the course for the first time in 1996 with seventeen students of whom slightly more than half - as it turned out - were either lesbian or gay. ${ }^{3}$ I prayed my students would not quickly discern my lack of confidence and my limited knowledge. I was a long way from "discovering my own voice." For their research papers, I insisted their topics focus on our Saskatchewan experience. I argued that we knew plenty about what was going on in Los Angeles, Boston, Toronto, and so on, but virtually nothing about our own experience at home. Late in the semester when students were submitting first drafts, I realized some of the work was of exceptional quality. During a coffee break, I exclaimed to a group of students that the results of their research should reach a larger audience than simply their professor. "We should hold a conference!" I exclaimed. And Breaking the Silence was born!

André: So that's how the Conference came to be. What has it been like since that pivotal event?

Don: At the close of our first conference, I declared rather boldly that this would not be a one-time event, that silence benefits the repressive status quo, and that we were in it for the long haul. I had little idea what would be involved in this declaration of faith! After five conferences, we have gained much confidence and valuable experience. It is for others to judge whether or to what extent we have been successful. Perhaps most importantly, we have learned that there is much latent support 'out there,' much more than we had ever imagined. People, we believe, need a path to channel their

${ }^{3}$ See Cochrane in the "Works Cited" for the current iteration of the course. 
positive beliefs, values, and commitments. The conference seems to have provided that space.

Several months before the fifth conference, I was asked by our education students' society to conduct an extracurricular workshop with the title "Why Are Straight Teachers So Silent in Defense of Their Lesbian and Gay Colleagues?" The event might seem trivial, but in our college it was rather remarkable. Seven years ago, no one would have dared or even have thought to ask. Back then issues surrounding lesbian and gay teachers and students were locked in a dark heterosexual closet, and no one knew where to find the key. In a politically progressive but socially conservative province such as Saskatchewan, we can say we have come a long way since 1996.

André: So after five successful conferences, you have no doubt learned a lot. What have you learned that you can share with others who want to do similar work in their own universities?

Don: Let me offer some 'how-to-do-it' suggestions:

Get Administrative Support: From the start, seek official approval for your LGBTQ proposal. In our case, the central administrative committee in our college gave our idea its blessing. Thus, all of our letters and posters could claim college of education sponsorship.

Set Up an Advisory Board: From the outset, create and make good use of an advisory board with wide representation. This is not only important for legitimacy, but also because it is these very people who have a wealth of ideas and contacts. Your board meetings become an important setting for sharing information and building coalitions, a benefit we never thought of at the start. In our case, advisory board members came from PFLAG (Parents, Family, and Friends of Gays and Lesbians); our college student society; the campus gay, lesbian, and bisexual center; faculty from the college and across the university; the Saskatchewan Teachers' Federation; teachers; and counselors.

Involve Senior Administration: Include administrators in your conference. They can bring official greetings, thank a speaker, or 
chair a panel. Symbolically, this is important, but these tasks also give your leadership a sense of ownership and shared achievement. (They need these outlets, too!) Later, when your conference has a sound track record, they will take genuine pride in noting your success in annual reports, at council meetings, and in speeches to various audiences.

Invite Guest Speakers: After our first year, we were emboldened to add a keynote speaker on the Friday evening before the Saturday conference proper. You need someone who will draw a crowd, and such persons normally command a hefty lecture fee. Our experience has been that such fees are negotiable, and that once the speakers learn what you are trying to accomplish, they will cut a deal that is much to your benefit.

Anticipate Opposition and Use It to Your Advantage: If you are doing some things right, you will attract the right wing! They may picket your conference, but this can be used to good advantage. All of those attending will know as they pass by the demonstrators that the 'problem' is real. Your straight participants need this reminder, especially. Notify your campus security well in advance. They will help to keep your conference safe.

Invite Community Stakeholders: Invite the stakeholders in your city and provincial educational systems to play a part in the program. A place on a panel is ideal. If they have something to contribute, you will have given them a bragging platform; if they waffle, it will be obvious to all. Invite them back next year to present a progress report.

Create Spaces for LGBTQ Voices: Early in each program, find a way to inject the voices of those who have suffered under heterosexist and homophobic oppression. If students and teachers do not think they can do this openly, record their voices and broadcast them over an auditorium sound system. Place empty chairs on the stage where they might have been seated if they were not living in fear. Curiously, their voices will be much more powerful when disembodied.

Create Spaces to Share LGBTQ Research: At first, I thought we would never be able to fill a whole one-day program with 
interesting presentations. We have never had a problem though. There is interesting work going on 'out there,' but few places to present it. Your venue becomes an outlet. After a couple of years, people begin to do research of various kinds with your conference in mind.

Invite the Media: We have found the media to be very sensitive and responsive. We treasure the relationships that have grown up over the years. Once they know you are there, they will call on you for comments and leads between conferences.

Think about Venue Suitability: Lastly, a word about location and costs. The university has great advantages. For many, it is neutral ground. A school board or teachers' association will not appear to be sponsoring, or 'promoting,' lesbian and gay liberation. Thus, teachers and administrators can attend more freely. Given that the university has a mandate to promote the open and rational discussion of controversial issues, the site is ideal. As there are many ways to cut costs on a campus, a conference can be relatively inexpensive. We have now run five on a shoestring. Our registration costs are very low, yet our nose is still above water.

\section{Interview Postscript}

Educators who take up LGBTQ struggles for human and civil rights hook their inclusive educational and cultural work to teaching as a vocation and to education for transformation. They are passionate and committed cultural workers who act as vigilant advocates for LGBTQ students and teachers. Don Cochrane is such an educator and cultural worker. In his teaching and in his work with the annual Breaking the Silence Conference, he continues to build awareness, to increase LGBTQ visibility. He demonstrates that teaching is both a pedagogical and political task requiring "the capacity to fight for freedom, without which the teaching task becomes meaningless" (Freire 4). As we take up this task "we study, we learn, we teach, we know with our entire body. We do all of these things with feeling, with emotion, with wishes, with fear, with doubts, with passion, and also with critical reasoning" (Freire 3 ). These words capture the dynamics of Don's involvement as well as that which he nurtures in participants in every Breaking the Silence Conference. 


\section{2 / Grace}

Indeed, listening to Don and watching him in action, I am reminded of Paulo Freire's (1998) notion of tolerance. This Brazilian critical educator - someone who focuses on matters of democracy, freedom, social justice, and ethics in everyday practice - maintains that tolerance is the quality that teaches us to live with difference, to respect it, and to learn from it. For Freire "tolerance is not coexistence with the intolerable ... Tolerance requires respect, discipline, and ethics" (42). Thus tolerance is about more than recognition of difference or even a passive, civil living with it. Rather, tolerance is about intersecting the cultural circles of different lives, coming to terms with difference as a sociohistorical construction, interrogating the politics of difference, and valuing and fostering difference in order to make cultural democracy a lived and everyday experience. Don's work incorporates this understanding of tolerance, and his initiatives - including Breaking the Silence - live it out.

\section{Works Cited}

Amnesty International. Crimes of Hate, Conspiracy of Silence:

Torture and Ill-Treatment Based on Sexual Identity. New York:

Amnesty International USA, 2001.

Cochrane, Don. "Edfdt 486.3: Gay and Lesbian Issues in Education."

Fall 2002. <http://www.usask.ca/education/coursework/ edfdt486/index.htm>.

Freire, Paulo. Teachers as Cultural Workers: Letters to Those Who Dare Teach. Boulder: Westview, 1998.

Katz, Melissa Saunders. "American Psychiatric Association Rebukes Reparative Therapy." American Psychiatric Association News Stand. 14 Dec. 1998 <http://www.psych.org/news_stand/ rep_therapy.cfm>.

Norman Institute. "Psychiatric Group Discredits 'Reparative' Therapy.” 1999. <http://www.authenticity.org/v1no1/apa399. html>.

Saskatchewan. The Saskatchewan Human Rights Code. 2000. <http:/ /www.qp.gov.sk.ca/documents/English/Statutes/Statutes/S241.pdf>. 